\title{
Initial results from geophysical surveys and shallow coring of the Northeast Greenland Ice Stream (NEGIS)
}

P. Vallelonga ${ }^{1}$, K. Christianson ${ }^{2,3}$, R. B. Alley $^{4}$, S. Anandakrishnan ${ }^{4}$, J. E. M. Christian ${ }^{3}$, D. Dahl-Jensen ${ }^{1}$, V. Gkinis ${ }^{1}$, C. Holme ${ }^{1}$, R. W. Jacobel ${ }^{3}$, N. B. Karlsson ${ }^{1}$, B. A. Keisling ${ }^{3,5}$, S. Kipfstuhl ${ }^{6}$, H. A. Kjær ${ }^{1}$, M. E. L. Kristensen ${ }^{1}$, A. Muto ${ }^{4}$, L. E. Peters ${ }^{4}$, T. Popp ${ }^{1}$, K. L. Riverman ${ }^{4}$, A. M. Svensson ${ }^{1}$, C. Tibuleac ${ }^{1}$, B. M. Vinther ${ }^{1}$, Y. Weng ${ }^{1}$, and M. Winstrup ${ }^{1}$

${ }^{1}$ Centre for Ice and Climate, Niels Bohr Institute, University of Copenhagen, Juliane Maries vej 30, Copenhagen 2100, Denmark

${ }^{2}$ Courant Institute of Mathematical Science, New York University, 251 Mercer St, New York, NY 10012, USA

${ }^{3}$ Physics Department, St Olaf College, 1520 St Olaf Ave, Northfield, MN 55057, USA

${ }^{4}$ Department of Geosciences and Earth and Environmental Systems Institute, The Pennsylvania State University, University Park, PA 16802-6813, USA

${ }^{5}$ Department of Geosciences, University of Massachusetts Amherst, 611 North Pleasant St., Amherst, MA 01003-9297, USA

${ }^{6}$ Alfred Wegener Institute, Am Handelshafen 12, 27570 Bremerhaven, Germany

Correspondence to: P. Vallelonga (ptravis@nbi.ku.dk)

Received: 26 November 2013 - Published in The Cryosphere Discuss.: 24 January 2014

Revised: 12 May 2014 - Accepted: 15 June 2014 - Published: 22 July 2014

\begin{abstract}
The Northeast Greenland Ice Stream (NEGIS) is the sole interior Greenlandic ice stream. Fast flow initiates near the summit dome, and the ice stream terminates approximately $1000 \mathrm{~km}$ downstream in three large outlet glaciers that calve into the Greenland Sea. To better understand this important system, in the summer of 2012 we drilled a $67 \mathrm{~m}$ firn core and conducted ground-based radio-echo sounding (RES) and active-source seismic surveys at a site approximately $150 \mathrm{~km}$ downstream from the onset of streaming flow (NEGIS firn core, $75^{\circ} 37.61^{\prime} \mathrm{N}, 35^{\circ} 56.49^{\prime} \mathrm{W}$ ). The site is representative of the upper part of the ice stream, while also being in a crevasse-free area for safe surface operations.

Annual cycles were observed for insoluble dust, sodium and ammonium concentrations and for electrolytic conductivity, allowing a seasonally resolved chronology covering the past $400 \mathrm{yr}$. Annual layer thicknesses averaged $0.11 \mathrm{~m}$ ice equivalent (i.e.) for the period 1607-2011, although accumulation varied between 0.08 and $0.14 \mathrm{~m}$ i.e., likely due to flowrelated changes in surface topography. Tracing of RES layers from the NGRIP (North Greenland Ice Core Project) ice core site shows that the ice at NEGIS preserves a climatic record of at least the past $51 \mathrm{kyr}$. We demonstrate that deep ice core
\end{abstract}

drilling in this location can provide a reliable Holocene and late-glacial climate record, as well as helping to constrain the past dynamics and ice-lithosphere interactions of the Greenland Ice Sheet.

\section{Introduction}

Mass loss of the Greenland Ice Sheet (GIS) is accelerating (Rignot et al., 2011) due to multiple processes that are not fully understood (Wouters et al., 2013). Approximately 50\% of net Greenland mass loss has been attributed to increased ice stream discharge, with other mass loss mechanisms including changing patterns of surface accumulation and runoff (van den Broeke et al., 2009). The mechanisms governing ice stream discharge are complicated, and include bedrock conditions as well as buttressing effects at the ice sheet margin. Changes in basal processes are difficult to monitor directly, but may have contributed to enhanced ice stream discharge. Faster ice flow may have increased frictional heating and thus basal melting of grounded ice, which is usually neglected in 
mass-balance estimates (van den Broeke et al., 2009), but may be locally significant.

A growing concern is the potential for additional rapid changes in ice dynamics that could contribute to further acceleration of mass loss. While the buttressing effect of floating glacier tongues (Moon et al., 2012) and the immediate effect of the melting of submarine ice tongues (Holland et al., 2008) have been widely studied, bedrock topography frequently limits the inland propagation of such effects, and glaciers may reset their flow rates to accommodate new geometries, with upstream mass loss limited to diffusive processes and their subsequent effects on surface mass balance (Bamber et al., 2013; Joughin et al., 2012b). Thus, current GIS mass loss due to ice-ocean interactions may be limited (kinematic constraints allow up to only $\sim 3 \times$ current mass loss rates for Jakobshavn Isbræ, Pfeffer et al., 2008), and many outlet glaciers will eventually stabilize once they encounter bed sills or withdraw from fjord troughs (Joughin et al., 2012a, b). An unknown in estimates of past and future mass loss of GIS is the behaviour of the northern Greenland Ice Sheet, where Atlantic Water (AW) reaching grounding lines currently remains relatively cold $\left(0-1{ }^{\circ} \mathrm{C}\right.$; Straneo et al., 2012), but may warm by several degrees in the next $100 \mathrm{yr}$ (Yin, 2012). Of principal importance are Petermann Glacier $\left(80^{\circ} 45^{\prime} \mathrm{N}, 60^{\circ} 45^{\prime} \mathrm{W}\right)$, and the Northeast Greenland Ice Stream (NEGIS), whose great inland extent may facilitate an especially rapid inland response to ocean-induced coastal thinning (Figs. 1, 2).

NEGIS is the largest ice stream in Greenland and is the only ice stream that extends so far inland (Fahnestock et al., 1993, 2001; Joughin et al., 2001). The onset of streaming flow is at the central ice divide, and the ice stream terminates in three large outlet glaciers (Nioghalvfjerds isstrømmen, Zachariae isbræ and Storstrømmen) approximately $1000 \mathrm{~km}$ downstream (Figs. 1, 2). NEGIS was first identified in 1993 using synthetic aperture radar (SAR) imagery (Fahnestock et al., 1993), with subsequent studies of bedrock topography and satellite radar interferometry (SRI) allowing evaluations of the velocity, mass balance, and basal characteristics of the ice stream (Fahnestock et al., 2001). The onset of the ice stream on the ice divide is likely caused by strong basal melt due to regionally high geothermal flux (Fahnestock et al., 2001; Petrunin et al., 2013), which results in enhanced lubrication and fast flow. The downstream acceleration of the ice stream (to $65 \mathrm{~m} \mathrm{yr}^{-1}$ approximately $200 \mathrm{~km}$ downstream from the ice divide, as shown in Figs. 2 and 3) is likely the result of basal water routing via ice-dynamic feedbacks and the presence of subglacial till, which will deform if sufficient pressurized subglacial water is present (Christianson et al., 2014). The role of NEGIS in the mass balance of the Greenland Ice Sheet is not well understood. For example, the inland effects of recent modest coastal acceleration following breakup of an ice shelf (Joughin et al., 2010) are poorly known due to sparse data and the relatively recent discovery of the ice stream (Fahnestock et al., 1993).
One of the factors contributing to the poor understanding of ice stream behaviour is the absence of deep ice cores obtained in and near areas of streaming ice flow. Most of the deep ice core drilling in Greenland has occurred along the central ice divide (Fig. 1) due to the slow ice flow there. Such ice core drilling projects prioritized climatic records and the accession of the oldest possible ice strata over the study of glacial hydrological processes. Due to the lower accumulation rate, inaccessibility and more complex ice dynamics of northeast Greenland compared to previous drilling sites, no deep ice coring projects have yet been launched for this vast area.

The closest deep ice coring was the NorthGRIP (NGRIP; North Greenland Ice Core Project) deep drilling program (NGRIP members, 2004), which obtained a continuous, well-preserved record of climate and impurities for the past $123 \mathrm{kyr}$. The ice core chronology obtained from NGRIP (Wolff et al., 2010) can be used to date radio-echo sounding (RES) layers at the NEGIS shallow core site $\left(75^{\circ} 37.61^{\prime} \mathrm{N}\right.$, $35^{\circ} 56.49^{\prime} \mathrm{W}$; Figs. 1-3) via tracing of continuous internal layers visible in airborne and ground-based RES data. Records of snow accumulation and deposition of sulfate and nitrate in northeast Greenland are available from firn and ice cores drilled during the 1993-1995 North Greenland Traverse (NGT) program (Fischer et al., 1998b). The NGT results demonstrate consistently lower snow accumulation rates to the east than to the west of the Greenland ice divide, and also highlight anthropogenic sulfate and nitrate production during the 20th century (Fischer et al., 1998a; Bigler et al., 2002). A $1200 \mathrm{yr}$ record of sulfate, calcium, and sodium at the $\mathrm{B} 20 \operatorname{site}\left(78^{\circ} 50^{\prime} \mathrm{N}, 36^{\circ} 30^{\prime} \mathrm{W} ; 2150 \mathrm{~m}\right.$ a.s.l. $)$ in northeast Greenland also demonstrated regular annual layer thicknesses of approximately $10 \mathrm{~cm}$ water equivalent (Bigler et al., 2002). The B20 core chronology was established primarily by the identification of volcanic deposition strata, although annual cycles in sulfate, calcium, and sodium were also detected and counted with a chronological uncertainty of $\pm 5 \mathrm{yr}$ between volcanic strata.

Here we present a detailed geophysical and glaciochemical study of the upstream section of NEGIS, concentrating on reconstructing recent climate history, and using newly acquired knowledge of ice dynamics to place this history in context. The geophysical data allows evaluations of the basal characteristics and flow dynamics of the ice stream, whereas the glaciochemical data allow past surface accumulation and impurity deposition to be reconstructed for the site. These data allow an improved estimate of the potential age of stratigraphically coherent ice layers that can be obtained from northeast Greenland. Furthermore, these findings are necessary for an improved understanding of the processes contributing to ice stream formation and dynamics as well as ice-lithosphere interactions. Our study also aids in the assessment of the stability of Greenland's only inland ice stream. This work indicates that additional field studies are necessary to understand the past and future behaviour of 


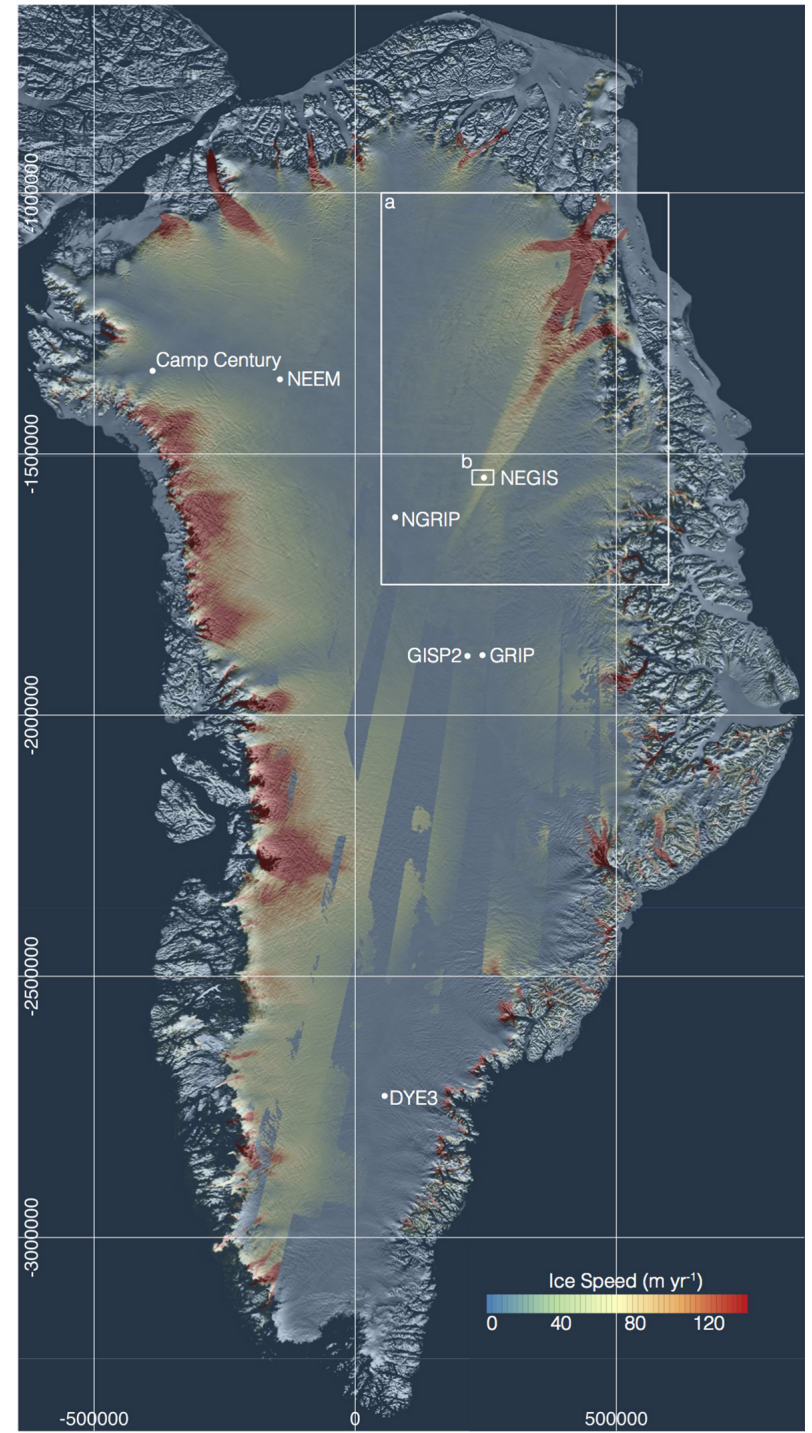

Figure 1. Locations of Greenland ice core drilling sites NEGIS, NEEM, NorthGRIP (NGRIP), GRIP, GISP2, DYE3, and Camp Century. The white boxes a and $\mathrm{b}$ denote the areas shown in Figs. 2 and 4, respectively. Velocities from interferometric synthetic aperture radar data are shown in colour (Joughin et al., 2010). Background is MODIS imagery (T. Haran, personal communication, 2012).

NEGIS, including its effect on the ice sheet mass balance and sea level.

\section{Methods}

\subsection{Firn core drill site}

In June 2012, a $67 \mathrm{~m}$ firn core was drilled at the NEGIS borehole site $\left(75.623^{\circ} \mathrm{N}, 35.96^{\circ} \mathrm{W}\right.$; Figs. 1-4). At the site, the ice flows $\sim 60 \mathrm{~m} \mathrm{yr}^{-1}$ horizontally to the northeast. The core was drilled in a dry borehole using a 3 in. diameter electrome- chanical drill. The firn core was cut into $55 \mathrm{~cm}$ bag lengths at the drill site and then packed for transport to the NEEM (North Greenland Eemian Ice Drilling) deep ice core drilling camp, where dielectric profiling (DEP) analysis (Moore et al., 1989) was conducted.

\subsection{Surface geophysical surveys}

Data presented here from ground-based geophysical surveys are restricted to those bearing on ice dynamics and basal conditions necessary to fully inform the interpretation of the shallow core. Two other publications (Christianson et al., 2014; Keisling et al., 2014) more fully discuss the geophysical data and resulting interpretations, including additional details on the basal interface and the distribution of internal layers both regionally and in the vicinity of the shallow core site. Christianson et al. (2014) directly examine the basal interface and its influence on ice dynamics using several geophysical techniques. Keisling et al. (2014) trace radar layers from NGRIP to NEGIS and infer variations in basal conditions from radar internal stratigraphy.

We collected $\sim 350$ line kilometres of kinematic GPS and RES data, five wide-angle seismic profiles, and five seismic shallow-refraction profiles in summer 2012. These experiments sampled areas of streaming flow and the adjacent slow moving ice (Fig. 4). RES and kinematic GPS profiles orthogonal to flow were separated by $2 \mathrm{~km}$; along-flow profiles in the central portion of the ice stream were separated by $\sim 5 \mathrm{~km}$ (Fig. 4). GPS data were processed using differential carrier-phase positioning (Chen, 1998) relative to a fixed nearby base station. RES data were collected using a monopulse system operating at a centre frequency of $\sim 3 \mathrm{MHz}$ (Welch and Jacobel, 2003; Welch et al., 2009). RES data processing included bandpass filtering, correction for antenna spacing, interpolation to standard trace spacing, two-dimensional migration, and correction for spherical divergence and englacial attenuation (Christianson et al., 2012; 2014). Grids of surface and bed elevation were interpolated using the nearest-neighbour algorithm, where bed elevation was calculated assuming a uniform radar wave speed in ice of $169 \mathrm{~m} \mathrm{us}^{-1}$ (Fig. 4). Unless otherwise stated, the projection is polar stereographic relative to the WGS84 (World Geodetic System 1984) ellipsoid with central meridian at $45^{\circ} \mathrm{W}$ and standard parallel at $70^{\circ} \mathrm{N}$. Surface elevation is relative to the WGS84 ellipsoid, and bed elevation/bathymetry is relative to the EIGEN-GL04C geoid.

At each seismic site (labelled A-E in Fig. 4), explosive sources and receivers were positioned to sample the same $480 \mathrm{~m}$ section of the bed over a continuous source-to-receiver offset of 0-4800 m (approximately $0-45^{\circ}$ incidence angle). Amplitude-vs.-offset (AVO) analysis of the ice bottom reflection (Peters et al., 2007, 2008; Peters, 2009; Aki and Richards, 2002) was performed to constrain elastic properties of the basal material. Shallow refraction profiles were 

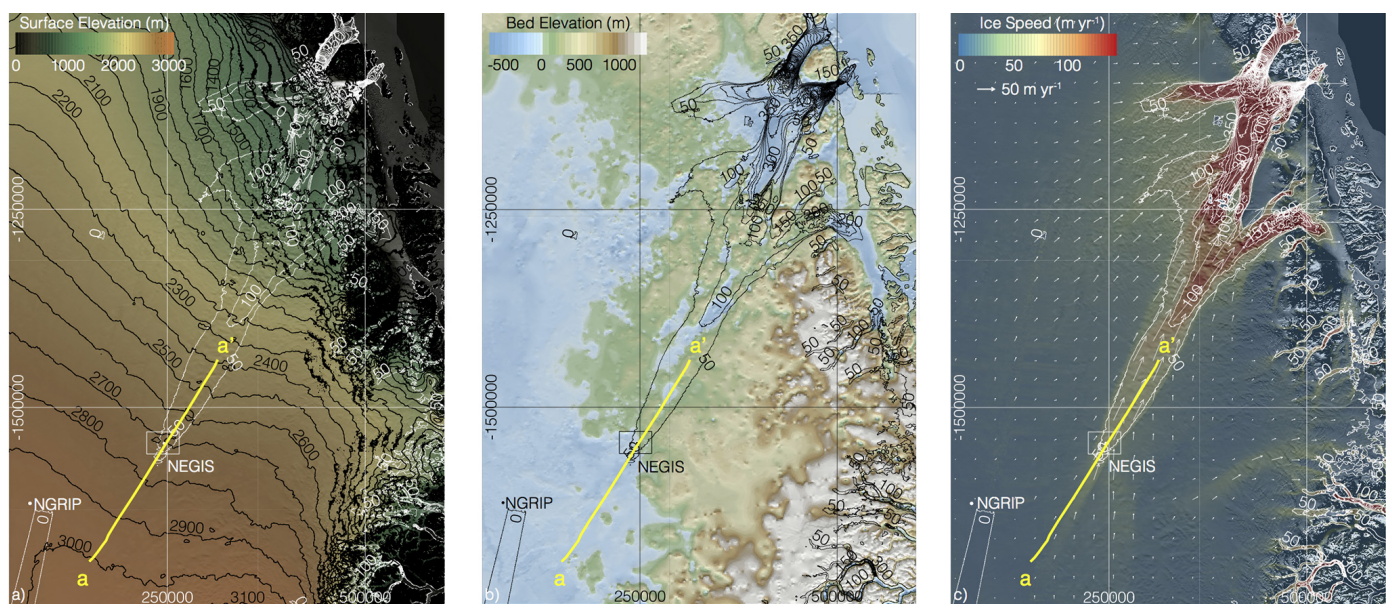

Figure 2. (a) Surface elevation, (b) bedrock elevation, and (c) ice velocity of northeast Greenland. Flow line aa' is shown in Fig. 3. White (black in b) box denotes area shown in Fig. 4. Surface elevation (black) and ice speed (white; black in b) contour intervals are $100 \mathrm{~m}$ and $50 \mathrm{~m} \mathrm{yr}^{-1}$, respectively. Bed elevation is from Bamber et al. (2013). Velocities are derived from interferometric synthetic aperture radar data (Joughin et al., 2010). Background imagery is MODIS (T. Haran, personal communication, 2012).

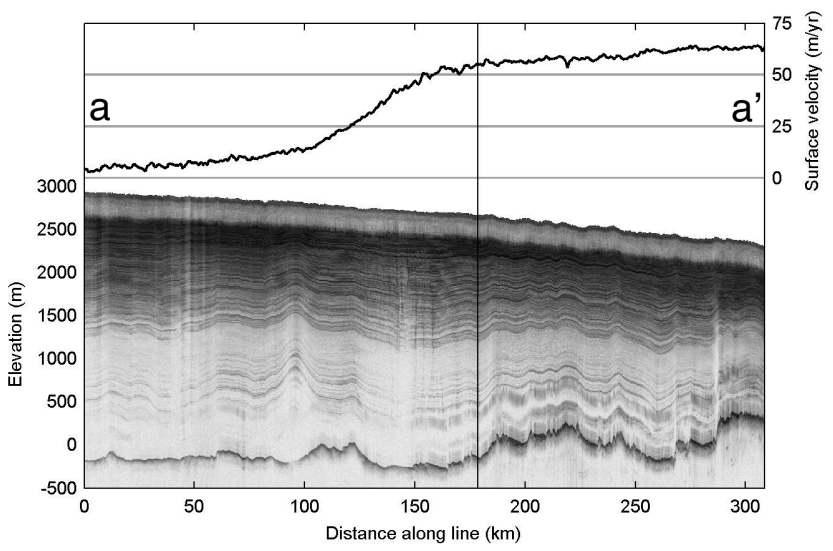

Figure 3. Surface velocities and radio-echo sounding internal layers along the NEGIS flow line aa' shown in Fig. 2. The abscissa is the along-flow distance, where 0 marks ice divide location. The location of the NEGIS firn core drilling site is shown by a vertical black line. Surface velocities are from Joughin et al. (2010). RES data were collected and processed by the Center for Remote Sensing of Ice Sheets (CReSIS), (Gogineni et al., 2012. MCORDS 19990525_01_010).

processed for firn depth and density following Kirchner and Bentley (1990) and Kohnen (1972), respectively.

\subsection{Ice core continuous flow analysis}

In January 2013, the NEGIS firn core was analysed using the continuous flow analysis (CFA) system developed at the CIC (Centre for Ice and Climate) for high-resolution analysis of ice cores. The CFA system was optimized for the determination of impurities in ice cores with a depth resolution of less than $1 \mathrm{~cm}$; therefore, the identification of annual lay- ers in the NEGIS firn core was achieved without difficulty. An example of the CFA system output is shown in Fig. 5. Density measurements and electrical conductivity measurements $(E C M)$ were conducted on the solid firn prior to cutting a $35 \mathrm{~mm} \times 35 \mathrm{~mm}$ longitudinal section for CFA (Kjær et al., 2013). The CFA system allows the continuous determination of impurities, such as sodium $\left(\mathrm{Na}^{+}\right)$, ammonium $\left(\mathrm{NH}_{4}^{+}\right)$, insoluble dust particles and electrolytic conductivity (Bigler et al., 2011) as well as stable water isotope ratios (Gkinis et al., 2011). Sodium concentrations were determined by optical absorption spectroscopy. Ammonium concentrations were determined by fluorescence spectroscopy. Both analytical techniques were calibrated using freshly prepared dilutions of standard solutions. The upper $20 \mathrm{~m}$ of the core was melted at a rate of $5 \mathrm{~cm} \mathrm{~min}^{-1}$, while the denser firn section was melted at a rate of $4 \mathrm{~cm} \mathrm{~min}^{-1}$. Blanks and calibration standards were determined at the start, middle, and end of each day of analysis, during which approximately $7 \mathrm{~m}$ of firn was melted.

\subsection{Water stable isotope analysis}

Samples for water stable isotope analysis were obtained from plastic tubes inserted into the snow surface (to $2 \mathrm{~m}$ depth) and from the NEGIS firn core (from $2 \mathrm{~m}$ to the bottom of the core). The tube samples were obtained from undisturbed snow within $10 \mathrm{~m}$ of the firn core drilling site. Both the tube samples and firn core were cut into $5 \mathrm{~cm}$ samples for stable isotope analysis. Thus, a total of 1325 discrete samples were collected from the surface down to $66.3 \mathrm{~m}$, with a sampling resolution of $5 \mathrm{~cm}$. The samples were melted in dry airtight metal containers and stored in $5 \mathrm{~mL}$ plastic containers. A total of $1.5 \mathrm{~mL}$ of each melted sample was pipetted into a $2 \mathrm{~mL}$ vial stored in a refrigerator to avoid evaporation 

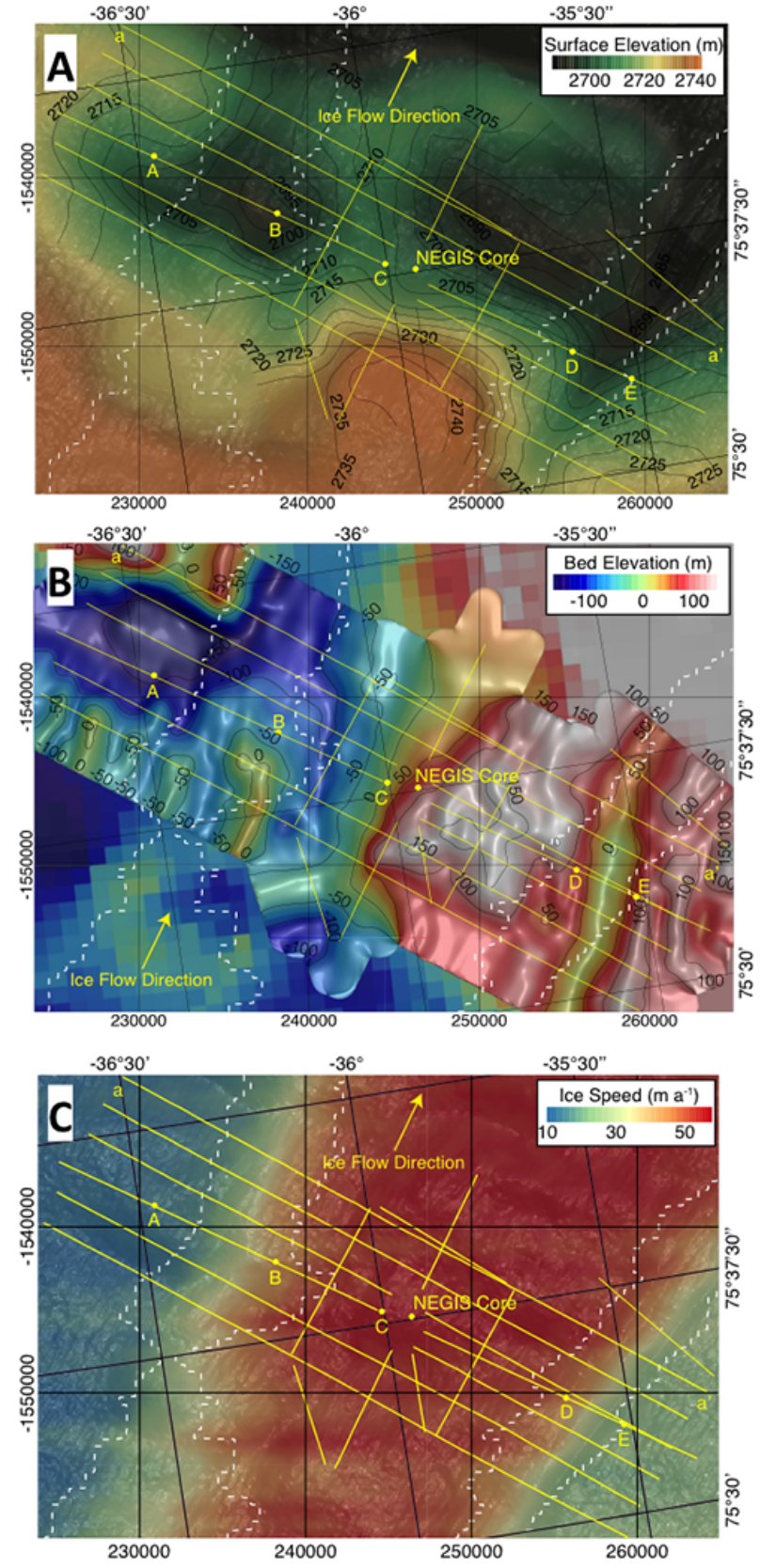

Figure 4. (a) Surface and (b) bedrock elevation of NEGIS interpolated from kinematic GPS profiles and RES profiles (yellow lines), respectively, and (c) ice speed in the vicinity of NEGIS (Joughin et al., 2010). Seismic sites are labelled A-E. Radar profile a-a' is shown in Fig. 6. The shallow core site (NEGIS core) is in the centre of the geophysical survey grid (yellow lines). In (a) black contours (1 $\mathrm{m}$ interval) show surface elevation (relative to WGS84 ellipsoid) and in (b) they show bed elevation ( $25 \mathrm{~m}$ interval). Background bed topography is from Bamber et al. (2013). In all figures, white dashed lines mark shear margins (areas with longitudinal strain rates greater than $2 \times 10^{-3} \mathrm{yr}^{-1}$ ). Background is MODIS imagery with Lambertian radiance applied (T. Haran, personal communication, 2012) in (a) and (c). between sampling and measurement. Each measurement run consisted of three standards and 39 discrete samples. To minimize the memory effect, each standard was injected 12 times and only the last five injections were used. Each discrete sample was injected four times and only the last three injections were used.

The samples were measured on a Picarro L2120-i nearinfrared cavity ring-down spectrometer (IR-CRDS) using the high throughput Picarro-A0212 vaporizer (Gkinis et al., 2011). The latter is superior to the more standard highprecision Picarro-A0211 vaporizer regarding memory effects. Considering the dependence of the IR-CRDS system on humidity levels, the water concentration was kept between 19000 and 20500 ppmv (parts per million by volume) during analyses. Results are reported with respect to Vienna Standard Mean Ocean Water (VSMOW) and normalized to the VSMOW-SLAP (Standard Light Antarctic Precipitation) scale using $\delta^{18} \mathrm{O}_{\mathrm{VSMOW}}=0.0 \%, \quad \delta^{18} \mathrm{O}_{\mathrm{SLAP}}=-55.5 \%$, $\delta D_{\text {VSMOW }}=0.0 \%$ and $\delta D_{\text {SLAP }}=-427.5 \%$. Note that this approach implies the use of a fixed two-point calibration line. We used three in-house standards with well-calibrated $\delta^{18} \mathrm{O}$ and $\delta D$ values with respect to the primary IAEA (International Atomic Energy Agency) standard waters. Two of the in-house standards are used for the estimation of the twopoint calibration line, and the third serves as a quality control. The overall precision of the system was determined to be better than $0.1 \%$ for $\delta^{18} \mathrm{O}$ and $0.5 \%$ for $\delta D$.

\subsection{Core chronology and annual layer counting techniques}

The NEGIS core chronology was established using the common technique of identifying volcanic deposition strata and then counting of annual layers determined from CFA measurements. For the top $3 \mathrm{~m}$ of the core, annual layer counting was based on the discrete $\delta^{18} \mathrm{O}$ annual cycles because the compacted snow was not suitable for CFA analysis. Volcanic strata were identified by DEP and confirmed using ECM and electrolytic conductivity measurements (Kjær et al., 2013). The main volcanic strata identified included Katmai (1912), Tambora (1816), unknown (1810), Laki (1783), and Komagatake (1640). Annual layers between volcanic strata were counted using two independent methods: a manual approach (Andersen et al., 2006) and an automated algorithm (Winstrup et al., 2012). The manual and algorithmic layer counting techniques were in agreement for all of the NEGIS record and confirmed the volcano-based estimate. Thus, we can determine the NEGIS core chronology to be accurate with a precision of $\pm 1 \mathrm{yr}$ for the past $\sim 400 \mathrm{yr}$. The age at the bottom of the core is $\mathrm{AD} 1607 \pm 1$. The annual layer thickness $(\lambda)$ was derived from the layer counting.

To extend the chronology of the NEGIS drill site beyond 1607, we used the NGRIP ice core chronology (Wolff et al., 2010) to date internal layers in airborne RES data connecting the NEGIS and NGRIP drill sites (Keisling et al., 
2014). As noted by Keisling et al. (2014), the layer continuity index is uniformly high in this region except in the ice stream shear margins, with numerous bright internal layers traceable for several hundred kilometres through the central portion of the ice sheet, allowing confident layer tracing. Internal layers were identified in and propagated through RES profiles using a semi-automatic algorithm that identifies the peak of the radar wavelet nearest an initial user-identified peak, then automatically selects the flanking changes in concavity, and finally follows this wavelet along a radar profile. As occasional user interaction is required, two independent interpreters informed the layer-tracing algorithm to eliminate user bias. We were able to identify 27 internal layers at NGRIP; 14 of these layers were continuous in airborne RES profiles between NGRIP and NEGIS (Keisling et al., 2014). Although the deepest continuous layer traceable from NGRIP to NEGIS is only $\sim 51 \mathrm{kyr}$, there is $\sim 600 \mathrm{~m}$ of additional ice present at NEGIS with many additional coherent internal layers present (Fig. 6; Keisling et al., 2014). Thus, the ice here is likely to be considerably older than $\sim 51 \mathrm{kyr}$. Although the uncertainty in this layer-tracing approach is significant, and increases with depth due to increasing uncertainty in both layer age and depth calculations, the uncertainty in the deepest layers is on the order of only a few thousand years. Internal layers in the deepest ice $(0-300 \mathrm{~m}$ above the bed) are blurry, and although there are traceable packets of energy, clear radar wavelets similar to a Ricker wavelet are not present. It is possible that stratigraphy in this deepest ice has been disturbed due to ice folding and overturning in a similar manner to ice in the deepest sections of the NEEM ice core (NEEM Community members, 2013).

\section{Results}

\subsection{NEGIS firn core chemistry}

The NEGIS impurity record shows stable values for all parameters over the past $400 \mathrm{yr}$, with the exception of conductivity, which varies during the second half of the 20th century (Fig. 7). Sodium is derived from sea salt inputs, and exhibits a regular peak in winter, likely due to increased winter storminess (Legrand and Mayewski, 1997). Mineral dust particles are transported to Greenland primarily in the spring/summer period, and have been geochemically linked to the Gobi and Taklamakan deserts in central Asia (Bory et al., 2003). No centennial-scale trends were observed in sodium or dust particles. Ammonium, originating from biogenic sources such as biomass burning, bacterial decomposition and soil emissions (Legrand et al., 1992), peaks in the summer, when temperatures are highest. Although diffusion has removed the annual signal of water isotope ratios, clear seasonality of the aforementioned chemical impurities can be observed in Fig. 5, such as anti-phasing of winter-deposited sodium and summer-deposited ammonium. The NEGIS record shows relatively few large ammonium peaks during the 20th century compared to previous centuries, which is consistent with other studies finding a decrease in large-scale boreal forest fires as a result of changes in grazing, agriculture and fire management practices, particularly in recent decades (Marlon et al., 2008). The electrolytic conductivity, which indicates the total ionic impurity loading in the ice, is elevated between 1950 and 2000, and peaks during the 1970s. The results agree with similar trends of sulfate and nitrate concentrations observed in the North Greenland traverse cores, and are attributed to industrial emissions from Europe and North America (Fischer et al., 1998b).

\subsection{Stable water isotopes}

The stable water isotopic composition in NEGIS firn is strongly smoothed by diffusion. The layer counting based on the discrete $\delta^{18} \mathrm{O}$ annual cycles is available for only the top $\sim 7 \mathrm{~m}$ of the core. Due to the difference between diffusion velocities of $\delta^{18} \mathrm{O}$ and $\delta D$, deuterium excess shows clear annual cycles until $\sim 10 \mathrm{~m}$ depth. Figure 5 shows the extent of diffusion at $30-32 \mathrm{~m}$ depths. The $\delta^{18} \mathrm{O}$ profile shows more-negative values from 30-45 m (Fig. 7), where the annual layer thickness is greater than in sections immediately above and below (Fig. 8). This feature of the profiles of $\delta^{18} \mathrm{O}$ and annual layer thickness was likely generated by the effect of upstream topographic undulations on accumulation, and advected to the core site by ice flow (Figs. 2-4; Reeh et al., 1985). The interplay between topographic undulations and accumulation effects will be discussed further in Sect. 4.1.

\subsection{Surface geophysical surveys}

\subsubsection{Surface topography}

Our focused survey and earlier regional analyses (Joughin et al., 2001; Fahnestock et al., 2001) show that the streaming flow and a broad surface depression are spatially coincident (Figs. 2a, 4), although, as discussed next, there is important topography within this broad surface depression correlated with features of the ice stream. Within the ice stream, elevation generally decreases from the ice sheet summit towards the coast, but there are numerous localized areas where elevation increases along-flow (Fig. 2a). The most distinct surface expression of NEGIS is the presence of well-defined troughs along the shear margins (Fig. 2; Fahnestock et al., 2001; Joughin et al., 2001). Unlike other ice streams, which have well-developed tributary systems (Rignot et al., 2011), the streaming flow in NEGIS is primarily supplied by ice that passes through a shear margin (Fig. 2c). The downstream widening reduces lateral drag on the ice after it has flowed through a shear margin, allowing strong velocity increase along-flow that favours surface thinning and a local low in surface elevation and basal hydropotential, in turn, 


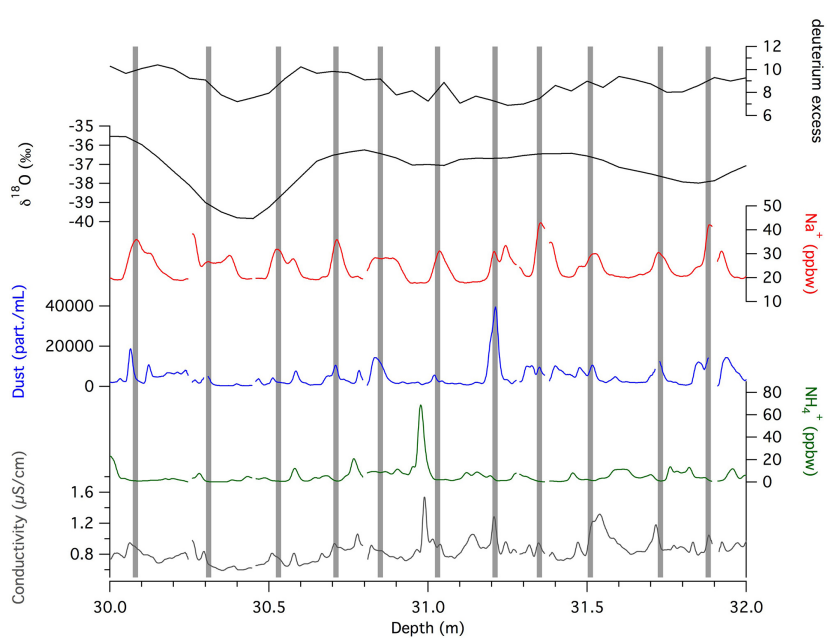

Figure 5. Stable water isotopologues and chemical impurities determined in the NEGIS firn core between 30 and $32 \mathrm{~m}$ depths. Vertical grey bars indicate assignment of annual layers, corresponding approximately to mid-winter (i.e. 1 January) of each year. $\delta^{18} \mathrm{O}$ and deuterium excess were determined in discretely cut ice sampled at $5 \mathrm{~cm}$ resolution while the impurities were determined from continuous flow analysis measurements. The $\delta^{18} \mathrm{O}$ and deuterium excess have been heavily diffused at this depth and no longer allow annual layer determination.

driving basal water routing roughly downstream and alongflow (Christianson et al., 2014).

\subsubsection{Bed topography}

Unlike most other ice streams, the region of fastest flow is not underlain by a prominent basal topographic trough (Figs. 2b4). The fastest flow in our survey region is actually over the area of highest bed elevation. The prominent surface troughs that mark the shear margins do not closely mirror bed topography; the northwest shear margin does somewhat overlie a shallow trough beneath, but the narrow basal trough on the southeast side runs approximately $15^{\circ}$ off-axis and terminates directly downstream of our ground-based survey (Figs. 2b, 4). Hydropotential is highest in the central portion of the ice stream, consistent with subglacial water flowing downstream and spreading as the ice stream widens, allowing enhanced lubrication and flow. Basal water routing along the shear margins is complex, and is further discussed in Christianson et al. (2014). In contrast to West Antarctic ice streams (Bell et al., 1998; Bingham et al., 2012), bed topography is not a primary control on the inland part of streaming flow in northeast Greenland. This agrees with other recent compilations of Greenland bed topography (Bamber et al., 2013; Fig. 2b), which show that prominent features in bed topography do not control current ice flow direction in northern Greenland.

\subsubsection{Basal lithology}

Full analysis of the basal interface using RES and activesource seismic data is detailed in Christianson et al. (2014). Here we discuss results relevant to ice dynamics in the vicinity of the shallow core site. Seismic AVO analysis allows us to determine elastic properties of the basal material (density, compressional-wave velocity, and shear-wave velocity), which, in turn, can be interpreted as an indicator of likely basal material. Our AVO analysis (Christianson et al., 2014) indicates the possibility of a dilatant till layer (several metres thick, approximately $35 \%$ porosity, $<100 \mathrm{kPa}$ effective pressure) at site $\mathrm{C}$, near the firn core site in the central part of the ice stream (Fig. 3). The subglacial sediment is somewhat more consolidated at sites B and D, one in each shear margin, with well-consolidated sediment at sites A and E outboard of the shear margins (Fig. 4). The pattern of radar basal reflectivity (Christianson et al., 2014) and hydropotential supports and extends the seismic data. After correcting for englacial attenuation and geometric spreading, radar basal reflectivity indicates that the central portion of the ice stream bed is wet, with water flow generally oriented along-flow. A hydropotential low beneath the surface trough of each shear margin acts as a barrier to both ingress and egress of subglacial water. These data suggest that streaming flow is due to basal lubrication caused by deforming sediment and high-pressure water in a manner similar to that seen on Siple Coast ice streams in West Antarctica (Peters et al., 2007, 2008; Blankenship et al., 1986; Alley et al., 1986; Kamb, 2001). The occurrence of sediment outside of streaming flow (sites A and E) suggests that streaming flow could shift location and possibly expand in response to redirection of subglacial water. Our seismic and radar surveys were designed to image the basal interface of NEGIS, rather than deeper geologic structures. Therefore, we cannot map the amplitude or spatial extent of the geothermal flux anomaly under portions of the ice stream, nor can we assess the presence or absence of a sedimentary basin under NEGIS similar to those under some West Antarctic ice streams (Anandakrishnan et al., 1998). Thus, additional field data are needed to understand the crustal structure of northeast Greenland and its effect on ice sheet behaviour.

\subsubsection{Firn characteristics}

Ice density profiles derived from seismic shallow-refraction data (Christianson et al., 2014) indicate that firn densification rates are significantly greater in the ice stream margins than in the central portions of the ice stream and outside of streaming flow (Fig. 9). As discussed by Alley and Bentley (1988), firn densification includes power-law-creep processes dependent on the second invariant of the stress tensor, especially for densities higher than $\sim 550 \mathrm{~kg} \mathrm{~m}^{-3}$. Thus, densification is accelerated by the ice flow stresses that cause surface strain rates. The high stresses causing the rapid side shear in the shear margins also produce faster firn densification rates. 


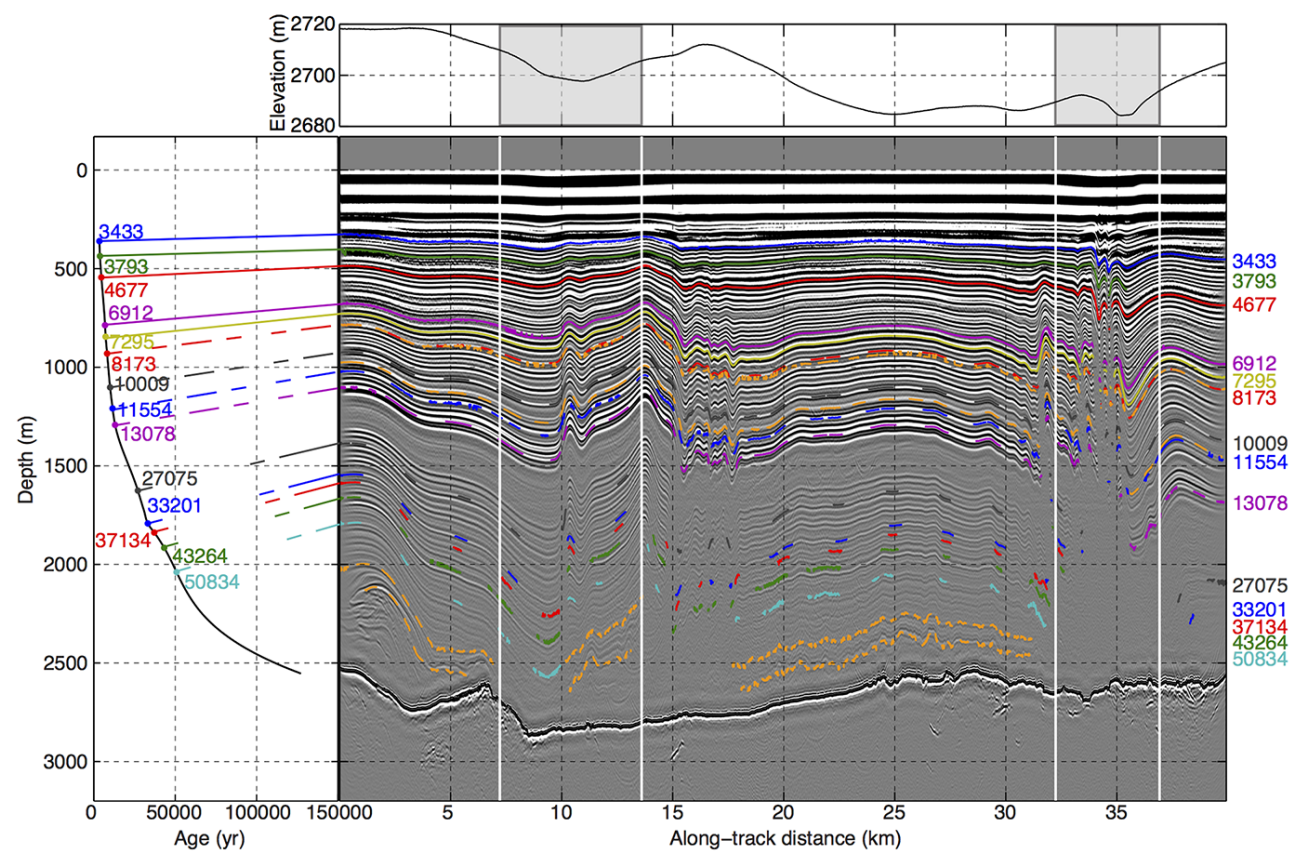

Figure 6. Profile a-a' (from Fig. 4) with dated internal layers. Age scale is assigned by tracing internal layers dated in the NGRIP core from NGRIP to NEGIS in airborne RES. Surface topography is from kinematic GPS data.

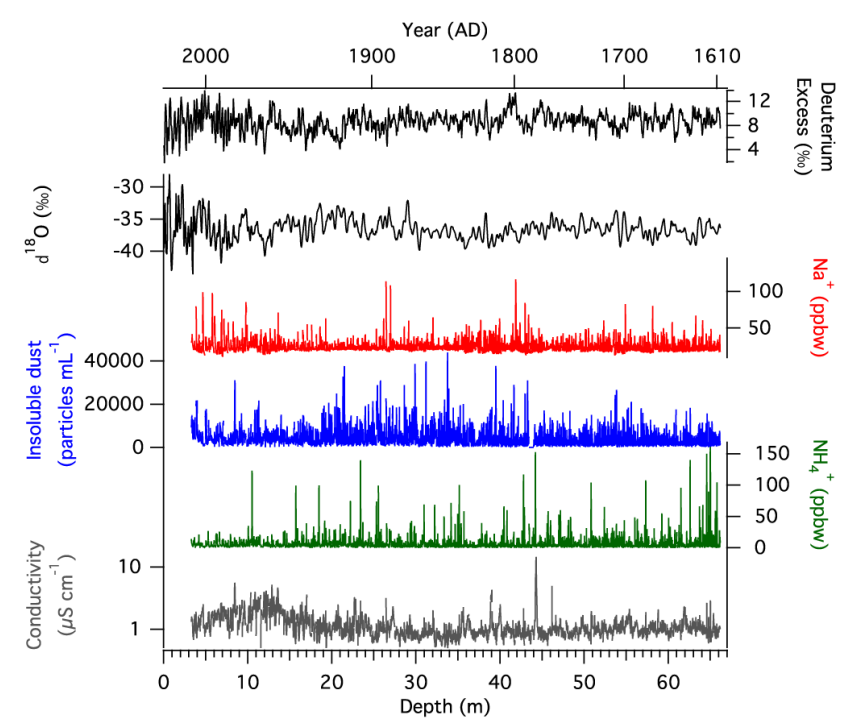

Figure 7. Stable water isotopologues and chemical impurities determined in the NEGIS firn core. $\delta^{18} \mathrm{O}$ and deuterium excess were determined in discretely cut ice sampled at $5 \mathrm{~cm}$ resolution while the impurities were determined from continuous flow analysis measurements.

In our survey, magnitudes of longitudinal strain rate greater than $2 \times 10^{-3} \mathrm{yr}^{-1}$ are associated only with the shear margins (Fig. 4c) and we use this strain contour to outline areas where enhanced firn densification is likely. We estimate from the seismic data that there is as much as $20 \mathrm{~m}$ of additional

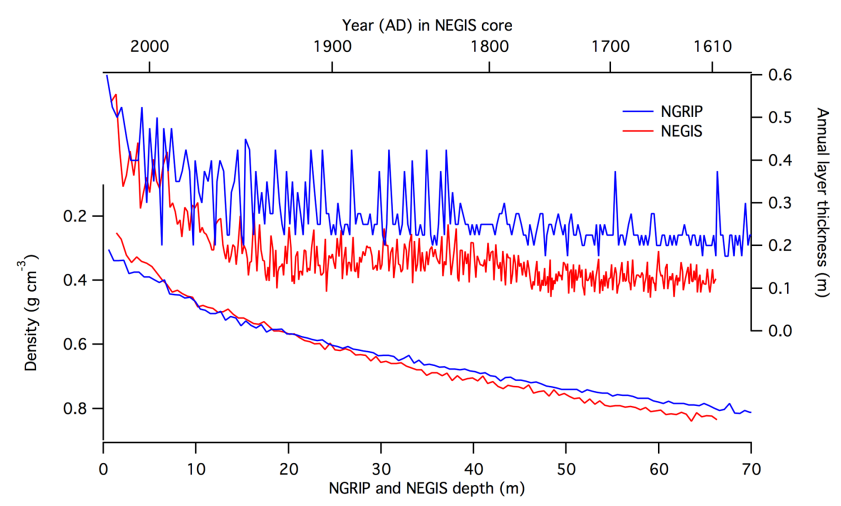

Figure 8. Annual layer thickness and density profiles for the NEGIS firn core and the upper $70 \mathrm{~m}$ of the NGRIP ice core.

ice in the shear margins (sites B and D in Figs. 2 and 4) compared to outside the ice stream for the same total thickness of firn and ice. This observation is significant for two reasons: (1) ice thickness and hydropotential are frequently calculated assuming a constant firn thickness of uniform density or no firn correction and (2) an ice core drilled in a shear margin or through a past shear margin will exhibit variations in density profiles and possibly crystal orientation fabric $(\mathrm{COF})$.

The surface troughs associated with the shear margins capture drifting snow, thereby increasing accumulation. Based on measured surface strain rates, Fahnestock et al. (2001) calculated that the maximum trough depth would be more than $200 \mathrm{~m}$, much more than observed, and suggested that 
enhanced accumulation in the troughs explains this difference, with implied rates in excess of $1 \mathrm{~m} \mathrm{yr}^{-1}$ of ice in this high, cold location. Our radar is designed primarily for sounding the full ice thickness and thus cannot see individual annual layers to trace their thickness change through the shear margins, but variations at the depth of the shallowest layer (300 $\mathrm{m}$ depth) fully support the inference of anomalously high accumulation in the shear margins $(8-15 \mathrm{~km} ; 33-$ $36 \mathrm{~km}$ in Fig. 6). Poorly defined and fuzzy, deep layers in the shear margins and within the ice stream may result from changes in crystal-orientation fabric due to ice flow through an area of variable strain rate (cf. NEEM Community members, 2013). From the observed velocity vectors, we calculate that the firn core consists entirely of accumulation from within the ice stream, and so is not affected by the accumulation anomalies of the troughs.

\section{Discussion}

\subsection{NEGIS accumulation profile}

The annual layer thickness profile determined for the NEGIS firn core demonstrates a reliable accumulation history for the past $400 \mathrm{yr}\left(\sim 0.11 \mathrm{~m}\right.$ i.e. $\left.\mathrm{yr}^{-1}\right)$. Although annual layer thicknesses (Fig. 8) vary gradually through the profile, the number of counted years corresponds well to volcanic tie points, confirming that loss of annual layers due to remobilization of surface snow is unlikely at the NEGIS site.

Sufficiently rapid ice flow over bed topography or variations in basal lubrication causes surface topography, in turn producing variations in accumulation rate from trapping of drift snow (e.g. Gow, 1965, for studies near Byrd Station, Antarctica; also see Reeh et al., 1985). Thus, any ice core located sufficiently far downstream is expected to exhibit accumulation variations. As shown in Fig. 4a, surface undulations are present in the vicinity of the NEGIS drill site (also see Fahnestock et al., 2001), so we expect accumulation rate variations in NEGIS ice cores. Figure 8 compares annual layer thickness profiles for NEGIS and the uppermost $70 \mathrm{~m}$ of the NGRIP ice core. Compared to the NGRIP profile, it is apparent that NEGIS annual layer thicknesses are anomalously low at two depth ranges, at $\sim 20 \mathrm{~m}$ and from $\sim 50$ to $\sim 60 \mathrm{~m}$ depths. The ice-equivalent annual layer thickness decreases from an average value of $0.12 \pm 0.02 \mathrm{mi}$.e. ( $1 \sigma$ error, 30 $40 \mathrm{~m}$ depth) to $0.09 \pm 0.01 \mathrm{~m}$ i.e. ( $1 \sigma$ error, $50-60 \mathrm{~m}$ depth), most likely due to advection of accumulation rate variability from an upstream area of enhanced surface topography.

The magnitude of the upstream effect can be calculated in a simple manner by applying the surface velocity field of NEGIS and assuming that horizontal velocities are constant for the uppermost $70 \mathrm{~m}$ of the firn column. Such assumptions show that the deepest strata of the NEGIS firn core originated approximately $21 \mathrm{~km}$ upstream of the drilling site. Figure 4a shows clear variations in the topography upstream of

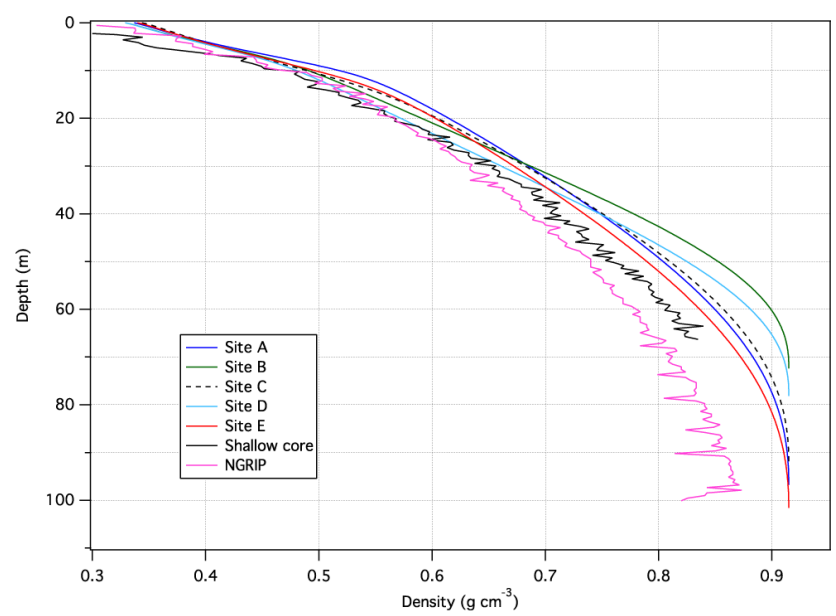

Figure 9. Firn density profiles determined from seismic shallow refraction data at sites A-E (Fig. 4). Note that density in all profiles approaches ice density $\left(917 \mathrm{~kg} \mathrm{~m}^{-3}\right)$ by $\sim 90 \mathrm{~m}$, but that the sites in the shear margins (B and D) exhibit higher densification rates. For comparison, the directly measured densities of the NEGIS shallow core (black line) and NGRIP ice core (pink line) are also plotted.

the NEGIS site within $21 \mathrm{~km}$ of the sampling site. Of particular note is a local high point approximately $7 \mathrm{~km}$ upstream of the NEGIS site and lower elevations observed farther upstream. The location of this surface feature corresponds to the AD 1860 firn stratum located at $30 \mathrm{~m}$ depth at NEGIS. This depression may collect blowing snow, which acts to increase the local accumulation and contribute to a thickening of the annual layers. The location of this upstream feature coincides with a local maximum of annual layer thickness at $30 \mathrm{~m}$ depth in the NEGIS firn core. If this local depression is indeed subject to blowing snow, this may induce a bias in the water isotope ratio of such features; if for example windblown snow tends to occur in winter, when gusts and storms are more frequent and stronger. This simple exercise illustrates the importance of investigating upstream topography for the interpretation of ice core records, particularly stable water isotopes, obtained from the NEGIS region. Such upstream effects have been previously described by Reeh et al. (1985) in the context of the Dye-3 ice core drilling site.

The stable shear margins (Fahnestock et al., 2001), with their very large effects on firn densification and snow accumulation rate, offer a unique laboratory for additional studies. The great range of strain rates and accumulation rates, with somewhat different conditions in the two shear margins at nearly the same temperature, should allow assessment of the role of different densification mechanisms (linear-viscous vs. power-law creep; e.g. Alley, 1987), and thus could lead to improved firn-densification modelling, which is of great value in ice core studies as well as for the overall projection of ice sheet models and reconstruction of past ice sheet flow. The anomalously enhanced accumulation rate in the shear margins may be the highest value that can be reliably 
sampled at such a low temperature. This suggests a useful target for studies requiring large volumes of ice, especially from recent times when identification of the anomaly is especially easy.

\subsection{NEGIS flow history and bedrock characteristics}

The lack of a topographic trough under the ice stream suggests that NEGIS is especially sensitive to subglacial water routing and feedbacks between ice thickness and subglacial erosion that influence hydropotential. Christianson et al. (2014) suggest the following extended hypothesis: a small region of high geothermal flux near the ice divide produces a plume of subglacial lubricating meltwater, giving NEGIS an inland origin. The plume spreads downstream in response to flow around basal obstacles in the absence of a strongly channelizing hydropotential gradient distribution, and this spreading, likely aided by ice flow processes, causes the ice stream to widen downstream (Alley and Whillans, 1991). Thus, the streaming flow is supplied almost entirely by ice that passes through a shear margin. The downstream widening reduces the lateral drag on ice after it has flowed through the shear margin, allowing strong velocity increase along-flow, which favours surface thinning and a local low in surface elevation and basal hydropotential. The resulting focusing of lubricating water leaves bands of poorly lubricated bed as part of the shear-margin complex, restricting ice and water flow into the ice stream. Therefore, inland ice does not form a broad catchment tightly coupled to marginal changes.

\subsection{Site selection considerations for future ice core studies}

Local accumulation rate, firn densification and surface velocity vary greatly in the upper reaches of NEGIS, thus offering a number of ideal sites for future ice-core-based studies of climate, firn processes, glaciology and glacial hydrology. Tracing of internal layers in RES data indicates that the upper section of the ice stream retains an intact stratigraphic climate record spanning at least $51 \mathrm{kyr}$. Studies of the area where streaming ice flow begins also offer a validation test for finite element method-based glaciological models such as Elmer. Ice core studies farther downstream along the NEGIS flow line will allow more extensive studies of the effects of fast-moving ice on ice sheet stratigraphy, as well as the basal hydrological conditions needed to maintain streaming flow. The extensive folds in internal layers imaged by RES in the deeper sections of NEGIS offer a particularly good opportunity to investigate ice rheology, crystal-fabric orientation and other physical parameters that contribute to deformation of deep ice in the Greenland Ice Sheet. Ice core and snow pit studies of the NEGIS shear margins also allow a rare glaciological environment for studying the physical deformation of ice strata as well as the effect of rapidly varying accumu- lation rates on the climate proxies commonly studied in ice cores.

\section{Conclusions}

We conducted an integrated geophysical and glaciochemical study on the Northeast Greenland Ice Stream, focusing on an area approximately $150 \mathrm{~km}$ east of the NGRIP ice core drilling site. The data presented here indicate that the NEGIS site retains a reliable, annually resolved record of chemical impurities including sodium, ammonium and mineral dust. A $67 \mathrm{~m}$ firn core drilled at the site was dated back to AD 1607, by a combination of annual layer counting as well as volcanic tie points. The surface accumulation has been relatively stable over the past $400 \mathrm{yr}$, although some variability has been observed due to upstream ice flow variability inducing irregular surface topography. Tracking of RES layers from NGRIP to the NEGIS site indicates that the NEGIS site preserves a stratigraphically intact climate archive of at least $51 \mathrm{kyr}$ duration. The character of the shear margins offers an outstanding opportunity to improve our understanding of firn densification, and to find recent samples with exceptionally high accumulation rates at such a low temperature. Deeper ice may contain information on past changes or ongoing processes in ice stream dynamics that are important to understand in order to properly incorporate NEGIS into models of the Greenland Ice Sheet, which is necessary to accurately forecast and hindcast ice sheet geometry and dynamics with their accompanying climatic ramifications.

Sufficiently large thinning along the ice stream from coastal forcing of the three outlet glaciers might remove the surface troughs and their effects, allowing NEGIS to tap a larger catchment area (Christianson et al., 2014). This possibility, plus a host of questions, such as the sources and transport of till, and whether the ice stream could have persisted over long times without eroding a trough, motivate additional observations and modelling. Additional seismic and radar data would aid in crustal structure mapping and determination of ice-lithosphere interaction in the vicinity of NEGIS. Additional data on past climate are also needed to allow proper incorporation of NEGIS into ice sheet models that will allow accurate past and future simulations of the Greenland Ice Sheet. The proximity of NEGIS to zones of deep water formation in the Greenland Sea, and the ability of NEGIS to rapidly discharge large amounts of ice, suggest it may have a unique ability to influence the southward transport of surface waters from the Greenland Sea, and ultimately Atlantic meridional ocean circulation. Thus, understanding the past and future behaviour is important not only to predict future sea level contributions, but also to understand past rapid changes in climate. 
Acknowledgements. The Alfred Wegner Institute, Kenn Borek Air, the 109th Wing of the New York Air National Guard, CH2MHILL Polar Resources, and the international North Greenland Eemian Ice Drilling (NEEM) project provided logistical support. We thank R. Smith for assistance with the CFA analyses. The Center for the Remote Sensing of Ice Sheets provided airborne RES data. UNAVCO provided GPS base station data. PASSCAL provided seismic instrumentation. QGIS and GMT were used to create some figures. The colour maps used are in the public domain or are licensed (unmodified) under the creative commons attribution share-alike 3.0 licence (2012) (http://creativecommons.org/licenses/by-sa/3.0/deed.fr; nwrc colour table from cpt-city module in QGIS). This project was funded by the Danish National Research Foundation (Centre for Ice and Climate), the US National Science Foundation (grant NSF OPP 0424589 - the Center for Remote Sensing of Ice Sheets) and NASA Operation IceBridge grant NNX13AD53A.

Edited by: E. Larour

\section{References}

Aki, K. and Richards, P. G.: Quantitative Seismology, 2 Edn., University Science Books, Sausalito, 2002.

Alley, R. B.: Firn densification by grain-boundary sliding: a first model, J. Phys.-Paris, 48, 249-254, doi:10.1051/jphyscol:1987135, 1987.

Alley, R. B. and Bentley, C. R.: Ice-core analysis on the Siple Coast of West Antarctica, Ann. Glaciol., 11, 1-7, 1988.

Alley, R. B. and Whillans, I. M.: Changes in the West Antarctic ice sheet, Science, 254, 959-963, doi:10.1126/science.254.5034.959, 1991.

Alley, R. B., Blankenship, D. D., Bentley, C. R., and Rooney, S. T.: Deformation of till beneath Ice Stream B, West Antarctica, Nature, 322, 57-59, doi:10.1038/322057a0, 1986.

Anandakrishnan, S., Blankenship, D. D., Alley, R. B., and Stoffa, P. L.: Influence of subglacial geology on the position of a West Antarctic ice stream from seismic observations, Nature, 394, 6265, doi:10.1038/27889, 1998.

Andersen, K. K., Svensson, A., Rasmussen, S. O., Steffensen, J. P., Johnsen, S. J., Bigler, M., Röthlisberger, R., Ruth, U., SiggaardAndersen, M.-L., Dahl-Jensen, D., Vinther, B. M., and Clausen, H. B.: The Greenland Ice Core Chronology 2005, 15-42 ka, Part 1: constructing the time scale, Quaternary Sci. Rev., 25, 32463257, doi:10.1016/j.quascirev.2006.08.002, 2006.

Bamber, J. L., Griggs, J. A., Hurkmans, R. T. W. L., Dowdeswell, J. A., Gogineni, S. P., Howat, I., Mouginot, J., Paden, J., Palmer, S., Rignot, E., and Steinhage, D.: A new bed elevation dataset for Greenland, The Cryosphere, 7, 499-510, doi:10.5194/tc-7499-2013, 2013.

Bell, R. E., Blankenship, D. D., Finn, C. A., Morse, D. L., Scambos, T. A., Brozena, J. M., and Hodge, S. M.: Influence of subglacial geology on the onset of a West Antarctic ice stream from aerogeophysical observations, Nature, 394, 58-61, doi:10.1038/27883, 1998.

Bigler, M., Wagenbach, D., Fischer, H., Kipfstuhl, J., Miller, H., Sommer, S., and Stauffer, B.: Sulphate record from a northeast Greenland ice core over the last 1200 years based on continuous flow analysis, Ann. Glaciol., 35, 250-256, doi:10.3189/172756402781817158, 2002.

Bigler, M., Svensson, A., Kettner, E., Vallelonga, P., Nielsen, M., and Steffensen, J. P.: Optimization of high-resolution continuous flow analysis for transient climate signals in ice cores, Environ. Sci. Technol., 45, 4483-4489, doi:10.1021/es200118j, 2011.

Bingham, R. G., Ferraccioli, F., King, E. C., Larter, R. D., Pritchard, H. D., Smith, A. M., and Vaughan, D. G.: Inland thinning of West Antarctic Ice Sheet steered along subglacial rifts, Nature, 487, 468-471, doi:10.1038/nature11292, 2012.

Blankenship, D. D., Bentley, C. R., Rooney, S. T., and Alley, R. B.: Seismic measurements reveal a saturated porous till layer beneath an active Antarctic ice stream, Nature, 322, 54-57, doi:10.1038/322054a0, 1986.

Bory, A. J.-M., Biscaye, P. E., Piotrowski, A. M., and Steffensen, J. P.: Regional variability of ice core dust composition and provenance in Greenland, Geochem. Geophy. Geosy., 4, 1107, doi:10.1029/2003GC000627, 2003.

Chen, G.: GPS kinematic positioning for airborne laser altimetry at Long Valley, Ph.D. thesis, Massachussetts Institute of Technology, Cambridge, MA, USA, 1998.

Christianson, K., Jacobel, R. W., Horgan, H. J., Anandakrishnan, S., and Alley, R. B.: Subglacial Lake Whillans - Ice-penetrating radar and GPS observations of a shallow active reservoir beneath a West Antarctic ice stream, Earth Planet. Sc. Lett., 331-332, 237-245, doi:10.1016/j.epsl.2012.03.013, 2012.

Christianson, K., Peters, L. E., Alley, R. B., Anandakrishnan, S., Jacobel, R. W., Riverman, K. L., Muto, A., and Keisling, B. A.: Dilatant till facilitates ice-stream flow in northeast Greenland, Earth Planet. Sci. Lett., 401, 57-69, doi:10.1016/j.epsl.2014.05.060, 2014.

Fahnestock, M. A., Bindschadler, R., Kwok, R., and Jezek, K.: Greenland ice sheet surface properties and ice dynamics from ERS-1 SAR imagery, Science, 262, 1530-1534, doi:10.1126/science.262.5139.1530, 1993.

Fahnestock, M. A., Joughin, I., Scambos, T. A., Kwok, R., Karbill, W. B., and Gogineni, S.: Ice-stream-related patterns of ice flow in the interior of northeast Greenland, J. Geophys. Res., 106, 34035-34045, doi:10.1029/2001JD900194, 2001.

Fischer, H., Wagenbach, D., and Kipfstuhl, J.: Sulfate and nitrate firn concentrations on the Greenland ice sheet 2. Temporal anthropogenic deposition changes, J. Geophys. Res., 103, 21935 21942, doi:10.1029/98JD01886, 1998a.

Fischer, H., Wagenbach, D., and Kipfstuhl, J.: Sulfate and nitrate firn concentrations on the Greenland ice sheet 1. Large-scale geographical deposition changes, J. Geophys. Res., 103, 21927 21934, doi:10.1029/98JD01885, 1998 b.

Gkinis, V., Popp, T. J., Blunier, T., Bigler, M., Schüpbach, S., Kettner, E., and Johnsen, S. J.: Water isotopic ratios from a continuously melted ice core sample, Atmos. Meas. Tech., 4, 25312542, doi:10.5194/amt-4-2531-2011, 2011.

Gogineni, P.: CReSIS MCORDS19990525_01_010 Data, Lawrence, Kansas, USA, Digital Media, http://data.cresis. ku.edu/ (last access: May 2014), 2012.

Gow, A. J.: On the accumulation and seasonal stratification of snow at the South Pole, J. Glaciol., 5, 467-477, 1965.

Holland, D. M., Thomas, R. H., De Young, B., Ribergaard, M. H., and Lyberth, B.: Acceleration of Jakobshavn Isbrae triggered 
by warm subsurface ocean waters, Nat. Geosci., 1, 659-664, doi:10.1038/ngeo316, 2008.

Joughin, I., Fahnestock, M., MacAyeal, D., Bamber, J. L., and Gogineni, P.: Observation and analysis of ice flow in the largest Greenland ice stream, J. Geophys. Res., 106, 34021-34034, doi:10.1029/2001jd900087, 2001.

Joughin, I., Smith, B. E., and Holland, D. M.: Sensitivity of 21st century sea level to ocean-induced thinning of Pine Island Glacier, Antarctica, Geophys. Res. Lett., 37, L20502, doi:10.1029/2010g1044819, 2010.

Joughin, I., Alley, R. B., and Holland, D. M.: Ice-Sheet Response to Oceanic Forcing, Science, 338, 1172-1176, doi:10.1126/science.1226481, 2012a.

Joughin, I., Smith, B. E., Howat, I. M., Floricioiu, D., Alley, R. B., Truffer, M., and Fahnestock, M.: Seasonal to decadal scale variations in the surface velocity of Jakobshavn Isbrae, Greenland: observation and model-based analysis, J. Geophys. Res., 117, F02030, doi:10.1029/2011jf002110, 2012b.

Kamb, B.: Basal Zone of the West Antarctic ice streams and its role in lubrication of their rapid motion, in: The West Antarctic Ice Sheet: Behavior and Environment, edited by: Alley, R. B. and Bindschadler, R. A., Antarctic Research Series, American Geophysical Union, Washington DC, 157-159, 2001.

Keisling, B. A., Christianson, K., Alley, R. B., Peters, L. E., Christian, J. E. M., Anandakrishnan, S., Riverman, K. L., Muto, A., and Jacobel, R. W.: Basal conditions and ice dynamics inferred from radar-derived internal stratigraphy of the Northeast Greenland Ice Stream, Ann. Glaciol., 55, 127-137, doi:10.3189/2014AoG67A090, 2014.

Kirchner, J. F. and Bentley, C. R.: RIGGS III: Seismic shortrefraction studies using an analytical curve-fitting technique, in: The Ross Ice Shelf: Glaciology and Geophysics, edited by: Bentley, C. R., and Hayes, D. E., Antarctic Research Series, American Geophysical Union, Washington DC, 1990.

Kjær, H. A., Vallelonga, P., Svensson, A., Kristensen, M. E. L., Tibuleac, C., and Bigler, M.: Continuous flow analysis method for determination of dissolved reactive phosphorus in ice cores, Environ. Sci. Technol., 47, 12325-12332, doi:10.1021/es402274z, 2013.

Kohnen, H.: On the relation between seismic velocities and density in firn and ice, Zeitschrift für Geophysik, 38, 925-935, 1972.

Legrand, M. and Mayewski, P.: Glaciochemistry of Polar ice cores: a review, Rev. Geophys., 35, 219-243, doi:10.1029/96RG03527, 1997.

Legrand, M., De Angelis, M., Staffelbach, T., Neftel, A., and Stauffer, B.: Large perturbations of ammonium and organic acids content in the Summit-Greenland ice core. Fingerprint from forest fires?, Geophys. Res. Lett., 19, 473-475, doi:10.1029/91GL03121, 1992.

Marlon, J. R., Bartlein, P. J., Carcaillet, C., Gavin, D. G., Harrison, S. P., Higuera, P. E., Joos, F., Power, M. J., and Prentice, I. C.: Climate and human influences on global biomass burning over the past two millennia, Nat. Geosci., 1, 697-702, doi:10.1038/ngeo313, 2008.

Moon, T., Joughin, I., Smith, B., and Howat, I.: 21st-century evolution of greenland outlet glacier velocities, Science, 336, 576578, doi:10.1126/science.1219985, 2012.

Moore, J. C., Mulvaney, R., and Paren, J. G.: Dielectric stratigraphy of ice: a new technique for determining total ionic concen- trations in polar ice cores, Geophys. Res. Lett., 16, 1177-1180, doi:10.1029/GL016i010p01177, 1989.

NEEM Community members: Eemian interglacial reconstructed from a Greenland folded ice core, Nature, 493, 489-494, doi:10.1038/nature11789, 2013.

NGRIP members: High-resolution record of Northern Hemisphere climate extending into the last interglacial period, Nature, 431, 147-151, doi:10.1038/nature02805, 2004.

Peters, L. E.: A seismic investigation of basal conditions in glaciated regions, Ph.D. thesis, The Pennsylvania State University, Pennsylvania, USA, 2009.

Peters, L. E., Anandakrishnan, S., Alley, R. B., and Smith, A. M.: Extensive storage of basal meltwater in the onset region of a major West Antarctic ice stream, Geology, 35, 251-254, doi:10.1130/G23222A.1, 2007.

Peters, L. E., Anandakrishnan, S., Holland, C. W., Horgan, H. J., Blankenship, D. D., and Voigt, D. E.: Seismic detection of a subglacial lake near the South Pole, Antarctica, Geophys. Res. Lett., 35, L23501, doi:10.1029/2008GL035704, 2008.

Petrunin, A. G., Rogozhina, I., Vaughan, A. P. M., Kukkonen, I. T., Kaban, M. K., Koulakov, I., and Thomas, M.: Heat flux variations beneath central Greenland's ice due to anomalously thin lithosphere, Nat. Geosci., 6, 746-750, doi:10.1038/ngeo1898, 2013.

Pfeffer, W. T., Harper, J. T., and O'Neel, S.: Kinematic constraints on glacier contributions to 21 st-century sea-level rise, Science, 321, 1340-1343, doi:10.1126/science.1159099, 2008.

Reeh, N., Johnsen, S. J., and Dahl-Jensen, D.: Dating the Dye 3 deep ice core by flow model calculations, in: Greenland Ice Cores: Geophysics, Geochemistry and the Environment, Geophy. Monog. Series, 33, American Geophysical Union, Washington DC, USA, 1985.

Rignot, E., Velicogna, I., van den Broeke, M. R., Monaghan, A., and Lenaerts, J. T. M.: Acceleration of the contribution of the Greenland and Antarctic ice sheets to sea level rise, Geophys. Res. Lett., 38, L05503, doi:10.1029/2011g1046583, 2011.

Straneo, F., Sutherland, D. A., Holland, D., Gladish, C., Hamilton, G., Johnson, H., Rignot, E., Xu, Y., and Koppes, M.: Characteristics of ocean waters reaching Greenland's glaciers, Ann. Glaciol., 53, 202-210, doi:10.3189/2012AoG60A059, 2012.

van den Broeke, M., Bamber, J., Ettema, J., Rignot, E., Schrama, E., van de Berg, W. J., van Meijgaard, E., Velicogna, I., and Wouters, B.: Partitioning recent greenland mass loss, Science, 326, 984 986, doi:10.1126/science.1178176, 2009.

Welch, B. C. and Jacobel, R. W.: Analysis of deep-penetrating radar surveys of West Antarctica, US-ITASE 2001, Geophys. Res. Lett., 30, 1444, doi:10.1029/2003GL017210, 2003.

Welch, B. C., Jacobel, R. W., and Arcone, S.: First results from radar profiles collected along the US-ITASE traverse from Taylor Dome to South Pole (2006-2008), Ann. Glaciol., 50, 35-41, doi:10.3189/172756409789097496, 2009.

Winstrup, M., Svensson, A. M., Rasmussen, S. O., Winther, O., Steig, E. J., and Axelrod, A. E.: An automated approach for annual layer counting in ice cores, Clim. Past, 8, 1881-1895, doi:10.5194/cp-8-1881-2012, 2012.

Wolff, E. W., Chappellaz, J., Blunier, T., Rasmussen, S. O., and Svensson, A.: Millennialscale variability during the last glacial: the ice core record, Quaternary Sci. Rev., 29, 2828-2838, doi:10.1016/j.quascirev.2009.10.013, 2010. 
Wouters, B., Bamber, J. L., van den Broeke, M. R., Lenaerts, J. T. M., and Sasgen, I.: Limits in detecting acceleration of ice sheet mass loss due to climate variability, Nat. Geosci., 6, 613-616, doi:10.1038/ngeo1874, 2013.
Yin, J.: Century to multi-century sea level rise projections from CMIP5 models, Geophys. Res. Lett., 39, L17709, doi:10.1029/2012g1052947, 2012. 